\title{
Optimization of the Hydrolysis of Conjugated $L$-DOPA, Dopamine and Dihydroxyphenylacetic Acid in Human Urine for Assay by High- Performance Liquid Chromatography with Electrochemical Detection
}

\author{
Päivi Tuomainen and Pekka T. Männistö ${ }^{1}$ )
}

University of Helsinki, Institute of Biomedicine, Department of Pharmacology and Toxicology, Helsinki, Finland

Summary: Conjugates of the catechol compounds, $L$-dihydroxyphenylalanine ( $L$-DOPA), dopamine and dihydroxyphenylacetic acid in human urine were analysed using the isocratic ion-pair reversed-phase HPLC method with electrochemical detection. Acid hydrolysis, using $4 \mathrm{~mol} / \mathrm{l} \mathrm{HCl}$ for $60 \mathrm{~min}$, was more effective than treatment with sulphatase for the generation of free catechols. Free (non-conjugated) catechols already present, as well as those produced by either of the hydrolysis procedures, were adsorbed onto aluminium oxide and extracted in acid solution. The repeatability of the technique for within and between-batch urine analysis was less than $2 \%$ and $8 \%$, respectively.

Free urinary dopamine (and dihydroxyphenylacetic acid) concentrations were much higher in the urine of patients treated with $L$-DOPA for Parkinson's disease than in healthy volunteers. At high dopamine (and dihydroxyphenylacetic acid) levels the conjugation capacity was apparently exceeded, since the overall percent conjugation of $L$ DOPA, dopamine and dihydroxyphenylacetic acid was decreased "concentration dependently" when the concentrations of free catechols were increased. Both in the control group and $L$-DOPA-treated groups, enzymatic hydrolysis was much less effective than acid hydrolysis in generating free catechols. This indicated that there were other, nonsulphated conjugates in the urine, accounting for between 66 and $100 \%$ of total conjugates.

\section{Introduction}

Conjugation reactions play a significant role in the metabolism of catecholamines and their oxidation products (1). Different analytical techniques have been used for determinations of catecholamines. HPLC methods with electrochemical or fluorescence detection have been described (2). A gas-chromatographic/mass-spectrometric method has also been reported (3). Liquid chromatography is the method of choice for the assay of catecholamines and metabolites, having the advantages of analytical sensitivity and selectivity. To measure the total concentrations of the catechols in urine, it is necessary to hydrolyse the samples before the HPLC analysis. Both enzymatic (4) and acid hydrolysis methods (5) have been used, but there is no consensus about how these methods should be optimally applied.

We found accidentally that the percentage release of dopamine and its metabolite, dihydroxyphenylacetic acid, from urine by hydrolysis, differed greatly for patients on $L$-dihydroxyphenylalanine ( $L$-DOPA) therapy and healthy subjects. It seemed that hydrolysis was inhibited either by the high catechol levels result-

\footnotetext{
1) Present address:

Department of Pharmacology and Toxicology, University of Kuopio, P. O. Box 1627, Fin-70211 Kuopio, Finland
}

ing from the $L$-DOPA therapy, or by dopa decarboxylase inhibitors.

These preliminary findings prompted us to study in detail some of the factors affecting enzymatic and acid hydrolysis. Free $L$-DOPA, dopamine and dihydroxyphenylacetic acid in urine, both before and after various hydrolysis procedures, were adsorbed onto aluminium oxide, then extracted into acidic solution. The concentrations of catechols were determined by ion-pair reversedphase chromatography and detected using an electrochemical detector. After the initial validation of the hydrolysis and analysis, the overall method was applied to clinical urine samples to compare the conjugation profile of catechols in the urine of healthy volunteers (very low dopamine levels) and patients treated with $L$-DOPA and dopa decarboxylase inhibitors (moderate or high dopamine concentrations).

\section{Materials and Methods}

Reagents

Ultrapure reagent-grade water was obtained with a Milli-Q system (Millipore Corporation, Milford, MA, USA). The solvents for chromatography were HPLC-grade (Rathburn, Walkerburn, UK) and the chemicals analytical grade. Aluminium oxide $\left(\mathrm{Al}_{2} \mathrm{O}_{3}\right)$, citric acid, disodium EDTA dihydrate, hydrogen chloride $(\mathrm{HCl})$, perchloric acid, phosphoric acid, sodium acetate, sodium chloride, sodium dihydrogen phosphate and sulphuric 
acid were purchased from E. Merck (Darmstadt, Germany). Dopamine, dihydroxyphenylacetic acid, $L$-DOPA, dihydroxybenzyl- amine, heptane sulphonic acid, tris(hydroxymethyl)aminomethane hydrochloride and arylsulphatase (aryl-sulphate sulphohydrolase; (a)

2

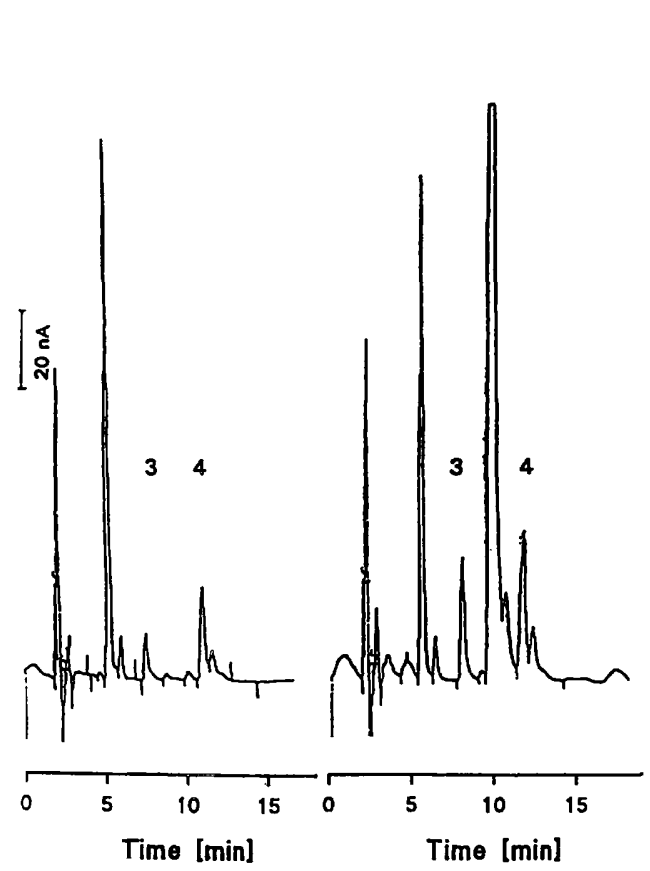

Fig. 1 Chromatograms derived from urine samples of the control subject. Urine sample:

(a) before acid hydrolysis,

(b) after acid hydrolysis $\left(4 \mathrm{~mol} / 1 \mathrm{HCl}\right.$ for $60 \mathrm{~min}$ at $95^{\circ} \mathrm{C}$ ),

(c) before enzymatic hydrolysis, (b)

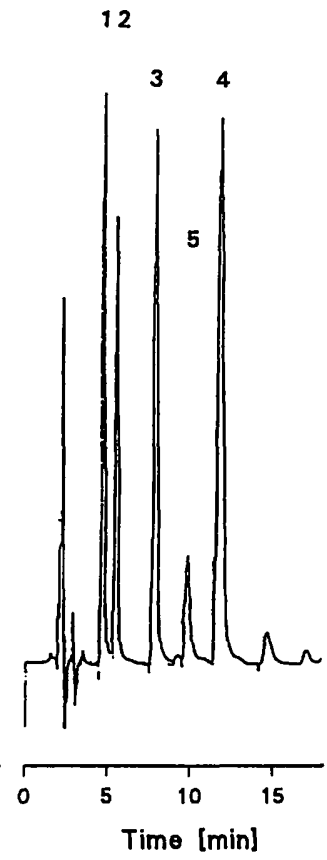

Fig. 2 Chromatograms derived from the urine samples of the patient treated with $L$-DOPA. Urine sample:
(a) before acid hydrolysis,
(b) after acid hydrolysis $\left(4 \mathrm{~mol} / \mathrm{l} \mathrm{HCl}\right.$ for $60 \mathrm{~min}$ at $95^{\circ} \mathrm{C}$ ).
(c) before enzymatic hydrolysis,

(c)

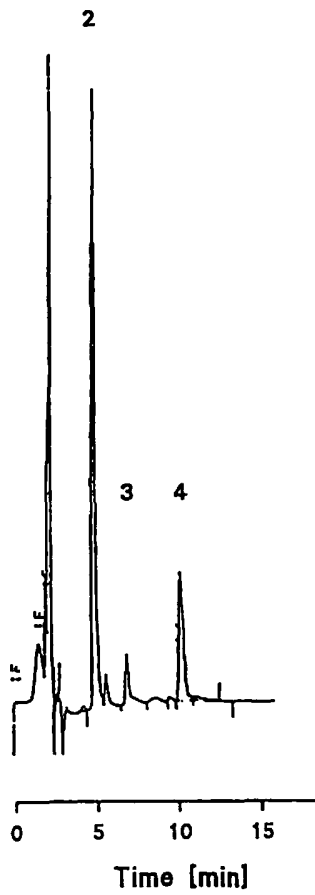

(d) after enzymatic hydrolysis (18.4 $\mathrm{U}$ sulphatase in $400 \mu$ reaction mixture for $60 \mathrm{~min}$ at $37^{\circ} \mathrm{C}$ ).

Peaks: 2 = dihydroxybenzylamine, 3 = dopamine, 4 = dihydroxyphenylacetic acid, $5=$ unknown extra peak.

(c)

(d)

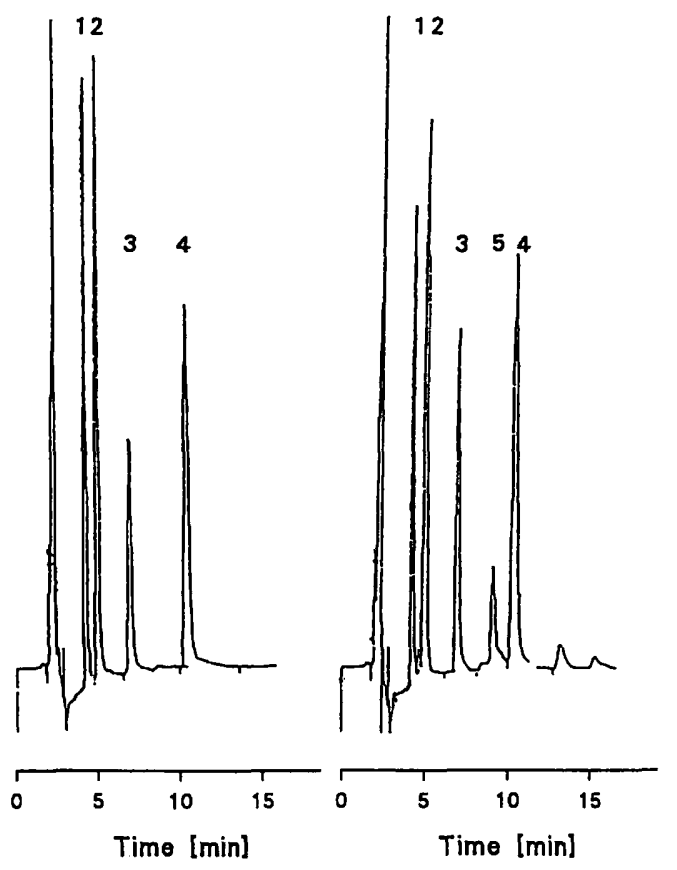

(d) after enzymatic hydrolysis ( $18.4 \mathrm{U}$ sulphatase in $400 \mu \mathrm{l}$ reaction mixture for $60 \mathrm{~min}$ at $37^{\circ} \mathrm{C}$ ).

Peaks: $1=L$-DOPA, $2=$ dihydroxybenzylamine, $3=$ dopamine, $4=$ dihydroxyphenylacetic acid, $5=$ unknown extra peak. 
Tab. 1 Intra- and inter-assay precision of analysis for dopamine, dihydroxyphenylacetic acid and $L$-DOPA in urine samples at two concentration levels $(n=4)$.

\begin{tabular}{llll}
\hline & Mean & $\begin{array}{l}\text { Intra- } \\
\text { assay CV } \\
(\%)\end{array}$ & $\begin{array}{l}\text { Inter- } \\
\text { assay CV } \\
(\%)\end{array}$ \\
\hline$L$-DOPA & $(\mathrm{mg} / \mathrm{l})$ & 1.6 & 7.7 \\
& 56.9 & 0.3 & 4.6 \\
Dopamine & 25.1 & 1.7 & 6.6 \\
& 56.5 & 2.0 & 6.7 \\
Dihydroxyphenyl- & 17.7 & 1.2 & 8.4 \\
acetic acid & 38.0 & 1.0 & 3.5 \\
\hline
\end{tabular}

EC 3.1.6.1; type H-1 from Helix pomatia) were purchased from Sigma (St. Louis, MO, USA).

\section{Standard solutions}

Stock solutions $(1 \mathrm{~g} / 1)$ of $L$-DOPA, dopamine and dihydroxyphenylacetic acid were prepared by dissolving the compounds in $0.4 \mathrm{~mol} / 1 \mathrm{HClO}_{4}$ containing $1 \mathrm{~g} / 1 \mathrm{Na}_{2} \mathrm{~S}_{2} \mathrm{O}_{5}$ and $150 \mathrm{mg} / 1$ EDTA. Working standard solutions, containing $2000 \mu \mathrm{g} / \mathrm{l}$ of each substance and internal standard dihydroxybenzylamine $(125 \mu \mathrm{g} / \mathrm{l})$, were prepared by diluting the stock solutions in the $0.4 \mathrm{~mol} / \mathrm{l}$ $\mathrm{HClO}_{4}$ solution. The stock solutions were stored at $+4{ }^{\circ} \mathrm{C}$ and used within 4 months. The working standard dilutions were prepared daily.

\section{Liquid chromatography}

The HPLC system consisted of an isocratic Waters Model 6000A pump with dual SSI suppressors in series, a Waters 712 Wisp autoinjector with cooler (Waters Association, Milford, MA, USA) and a Hewlett-Packard 3396 series II recording integrator (Palo Alto,
CA, USA). An analytical cell 5011 of ESA Coulochem Model $5100 \mathrm{~A}$ coulometric detector (ESA, Inc, USA) set at $+0.10 \mathrm{~V} /-$ $0.30 \mathrm{~V}$ with conditioning cell 5021 set $+0.50 \mathrm{~V}$ was used. Spherex $5 \mathrm{C} 18$ column $(5 \mu \mathrm{m}, 125 \times 4.6 \mathrm{~mm}$ I. D., Phenomex, Torrance, CA, USA) with Separon SGX C18 precolumn was used for analytical separations.

The isocratic mobile phase contained $0.1 \mathrm{~mol} / 1 \mathrm{Na}_{2} \mathrm{HPO}_{4}, 0.15$ $\mathrm{mmol} / 1 \mathrm{EDTA}, 20 \mathrm{mmol} / 1 \mathrm{citric}$ acid, $1.0 \mathrm{mmol} / \mathrm{l}$ heptane sulphonic acid and methanol, volume fraction $0.1, \mathrm{pH} 3.0$. This filtered eluent was degassed before use. The flow rate was $0.7 \mathrm{ml} / \mathrm{min}$. The individual compounds were screened by comparing their absolute retention times with those of the standard compounds.

\section{Sample preparation}

The urine samples from 7 patients with Parkinson's disease were collected during $2-4 \mathrm{~h}$ after the first morning dose (6). Similarly, the urine samples of 5 healthy control subjects without drug therapy were collected. The specimens were taken into plastic bottles containing $2.5 \mathrm{ml}$ of $6 \mathrm{~mol} / / \mathrm{HCl}$ as a preservative and stored at $-20^{\circ} \mathrm{C}$ until assay.

Free catechol compounds from urine were selectively extracted onto $\mathrm{Al}_{2} \mathrm{O}_{3}$ before quantification based on the modification of a previous method (7). One millilitre of diluted urine sample $(1: 2$ or $1: 20$ in healthy controls and $1: 20$ or $1: 200$ in patients on $L$ DOPA therapy; see below) was mixed with $600 \mu \mathrm{l}$ of $1.5 \mathrm{~mol} / \mathrm{l}$ Tris- $\mathrm{HCl}$ buffer $\mathrm{pH} 8.6$ and placed on $50 \mathrm{mg}$ of $\mathrm{Al}_{2} \mathrm{O}_{3}$, after which $10 \mu \mathrm{l}$ of internal standard containing $125 \mathrm{ng}$ of dihydroxybenzylamine was added. The $\mathrm{pH}$ of the sample was kept between 8.5 and 8.7. The samples were mixed in a shaker for $10 \mathrm{~min}$ and centrifuged $\left(10 \mathrm{~min}\right.$ at $2000 \mathrm{~g}$ at $\left.+4{ }^{\circ} \mathrm{C}\right)$ after which the supernatants were aspirated. The $\mathrm{Al}_{2} \mathrm{O}_{3}$ was washed twice with $1.5 \mathrm{ml}$ of water. $L$-DOPA, dopamine and dihydroxyphenylacetic acid were extracted by shaking the samples for $10 \mathrm{~min}$ with $1 \mathrm{ml}$ of $0.4 \mathrm{~mol} / 1$ $\mathrm{HClO}_{4}$ containing $1 \mathrm{~g} / 1 \mathrm{Na}_{2} \mathrm{~S}_{2} \mathrm{O}_{5}$ and $150 \mathrm{mg} / 1$ EDTA. After centrifugation the supernatant was filtered (Acrodisc LC filter, $0.45 \mu \mathrm{m}$, Gelman Sciences, Ann Arbor, MI, USA) into a HPLC tube and

Tab. 2 Enzymatic hydrolysis of urine samples taken from healthy control subjects and $L$-DOPA treated patients with sulphatase for $60 \mathrm{~min}$ at $37^{\circ} \mathrm{C}$.

\begin{tabular}{|c|c|c|c|c|c|c|}
\hline & \multirow[t]{2}{*}{$\mathbf{n}$} & \multicolumn{2}{|c|}{ Control subjects } & \multirow[t]{2}{*}{$\mathbf{n}$} & \multicolumn{2}{|c|}{$L$-DOPA-treated patients } \\
\hline & & $\begin{array}{l}\text { Concentration } \\
(\mathrm{mg} / \mathrm{l})^{\mathrm{a}}\end{array}$ & $\begin{array}{l}\text { Efficacy of } \\
\text { hydrolysis }^{b}\end{array}$ & & $\begin{array}{l}\text { Concentration } \\
(\mathrm{mg} / \mathrm{l})^{\mathrm{a}}\end{array}$ & $\begin{array}{l}\text { Efficacy of } \\
\text { hydrolysis }^{\mathrm{b}}\end{array}$ \\
\hline \multicolumn{7}{|l|}{$\mathrm{L}-D O P A$} \\
\hline Control & & & & 2 & $\begin{array}{l}28.6 \\
28.2\end{array}$ & \\
\hline $9.2 \mathrm{U}$ sulphatase & & - & & 5 & $27.4 \pm 0.9$ & -3.2 \\
\hline 18.4 U sulphatase & & - & & 2 & $\begin{array}{l}28.2 \\
28.3\end{array}$ & -0.5 \\
\hline \multicolumn{7}{|l|}{ Dopamine } \\
\hline Control & 4 & $0.34 \pm 0.01$ & & 2 & $\begin{array}{l}12.4 \\
12.2\end{array}$ & \\
\hline $9.2 \mathrm{U}$ sulphatase & 8 & $0.47 \pm 0.02$ & 40 & 5 & $19.8 \pm 0.4$ & 61 \\
\hline 18.4 U sulphatase & 4 & $0.52 \pm 0.01$ & 55 & 2 & $\begin{array}{l}22.8 \\
22.5\end{array}$ & 84 \\
\hline \multicolumn{7}{|c|}{ Dihydroxyphenylacetic acid } \\
\hline Control & 4 & $1.39 \pm 0.03$ & & 2 & $\begin{array}{l}28.7 \\
28.4\end{array}$ & \\
\hline $9.2 \mathrm{U}$ sulphatase & 8 & $1.52 \pm 0.04$ & 9 & 5 & $40.8 \pm 0.7$ & 43 \\
\hline 18.4 U sulphatase & 4 & $1.60 \pm 0.02$ & 15 & 2 & $\begin{array}{l}40.3 \\
39.8\end{array}$ & 40 \\
\hline
\end{tabular}

\footnotetext{
a Mean $\pm \mathrm{SD}$

b $\frac{\text { After hydrolysis }- \text { Before hydrolysis }}{\text { Before hydrolysis }} \times 100$
} 
stored at $-80^{\circ} \mathrm{C}$ for chromatography. A $20 \mu$ l aliquot of sample was injected into HPLC system.

\section{Enzymatic hydrolysis of urine samples}

To reveal the presence of sulphate conjugates of catechol compounds, aliquots $(100 \mu \mathrm{l})$ of diluted urine $(1: 2$ or $1: 20$ using 0.02 $\mathrm{mol} / 1 \mathrm{HCl}$ in the samples of healthy controls and patients on $L$ DOPA therapy, respectively) were buffered with $200 \mu \mathrm{l}$ of $0.2 \mathrm{~mol} / \mathrm{l}$ acetate buffer, $\mathrm{pH} 5$, and treated with arylsulphatase $(9.2$ or 18.4 units) dissolved in $100 \mu \mathrm{l}$ of ice cold $2 \mathrm{~g} / \mathrm{l}$ sodium chloride solution. The incubation time was $1 \mathrm{~h}$ at $+37^{\circ} \mathrm{C}$. The reaction was stopped placing in an ice bath. The hydrolysed sample was adsorbed onto $\mathrm{Al}_{2} \mathrm{O}_{3}$ and extracted as above.

\section{Acid hydrolysis of urine samples}

To compare the hydrolysis of conjugated catecholamines with different acids, $150 \mu \mathrm{l}$ of either $4 \mathrm{~mol} / 1 \mathrm{HCl}, 4 \mathrm{~mol} / 1 \mathrm{HClO}_{4}$ or $4 \mathrm{~mol} / 1$ $\mathrm{H}_{2} \mathrm{SO}_{4}$ were added to $1 \mathrm{ml}$ of a diluted urine sample $(1: 20$ or $1: 200$ with the solution containing $1 \mathrm{~g} / 1$ of $\mathrm{Na}_{2} \mathrm{~S}_{2} \mathrm{O}_{5}$ and $150 \mathrm{mg} / 1$ EDTA in samples of healthy controls and patients on $L$-DOPA therapy, respectively), and incubated for $60 \mathrm{~min}$. To detect the effect of time on hydrolysis with $4 \mathrm{~mol} / 1 \mathrm{HCl}$, various incubation times $(30,60,90$ and $120 \mathrm{~min})$ were used. This mixture was heated for $1 \mathrm{~h}$ at $+95^{\circ} \mathrm{C}$ in an oven and then cooled on ice. Finally, it was adsorbed onto $\mathrm{Al}_{2} \mathrm{O}_{2}$ and desorbed into acidic solution as above.

\section{Calibration and calculation}

For each HPLC run the method was calibrated with 5 concentrations $(10-400 \mu \mathrm{g} / 1)$ of calibration samples of $L$-DOPA, dopamine and dihydroxyphenylacetic acid, containing internal standard (125 $\mu \mathrm{g} / \mathrm{l}$ of dihydroxybenzylamine). Peak-height ratios of each compound to internal standard, obtained from actual standards, were plotted against the concentrations of each substance to generate a linear least-squares regression line with QuattroPro software (Borland International, Scotts Valley, CA, USA). The reliability was assessed by calculating the intra-assay and inter-assay coefficient of variation $(\mathrm{CV})$.

\section{Results}

Liquid chromatography of $L$-DOPA, dopamine and dihydroxyphenylacetic acid

$L$-DOPA, dopamine and dihydroxyphenylacetic acid were detected simultaneously in urine samples by isocratic ion-pair reversed-phase HPLC (figs. 1 and 2). Before the chromatographic separation, it was necessary to perform an alumina absorption to remove non-catechol compounds and impurities in matrices.

Because electrochemical detection was used, the calibration had to be performed separately for each analyte. The electrical responses (heights) were linear with correlation coefficients of more than 0.999 for the standard compounds from 10 to $400 \mu \mathrm{g} / \mathrm{l}$. The detection limit of the assay (peak height three times the baseline noise) was $10 \mathrm{pg}$ for dopamine and $L$-DOPA and $15 \mathrm{pg}$ for dihydroxyphenylacetic acid.

The assay of free compounds indicates the repeatability of the technique for both within and between-batch urine analysis at the two concentration levels studied (tab. 1). The intra-assay CVs varied between $0.3 \%$ and $2 \%$, whereas inter-assay CVs were between $3.5 \%$ and $8.4 \%$.
In the acid hydrolysis using $4 \mathrm{~mol} / \mathrm{l} \mathrm{HCl}$, analytical recoveries of $200 \mu \mathrm{g} / \mathrm{l}$ were $82.3 \%, 82.2 \%$ and $88.2 \%$ with CV\% 1.5, 1.8 and 2.0 for $L$-DOPA, dopamine and dihydroxyphenylacetic acid standards, respectively. In the enzymatic hydrolysis, the recoveries of $200 \mu \mathrm{g} / \mathrm{l}$ of the three compounds were $88.5 \%, 89.0 \%$ and $92.6 \%$ with CV\% of 9.7, 6.8 and 9.4, respectively. After spiking urine samples with $100 \mu \mathrm{g} / \mathrm{l}$ of each standard, the recoveries of $L$-DOPA, dopamine and dihydroxyphenylacetic acid were $82.6 \pm 6.7 \%$ (mean \pm CV\%), $85.9 \pm 6.7 \%$ and $91.0 \pm 7.4 \%$, respectively.

\section{Enzymatic hydrolysis of urine samples}

The effect of two arylsulphatase concentrations (9.2 and $18.4 \mathrm{U}$ in two samples after $60 \mathrm{~min}$ incubation $(30 \mathrm{~min}$ suggested by the supplier) is shown in table 2 . Incubation times exceeding 60 min did not increase but rather decreased the amount of deconjugated compounds (data not shown). The use of a sulphatase preparation (type-1) from Helix pomatia did not interfere with the chromatography.

The enzymatic hydrolysis was found to be strongly inhibited in the presence of $1 \mathrm{mmol} / 1$ of $\mathrm{Na}_{2} \mathrm{~S}_{2} \mathrm{O}_{5}$. Sulphatase was also weakly active when the hydrolysis was performed in phosphate buffer (data not shown). It was not feasible to run the internal standard through the hydrolysis process since it was significantly decomposed during incubation. Therefore the internal standard was added at the alumina absorption stage, where its recovery was satisfactory $(89.2 \%)$.

\section{Acid hydrolysis of urine samples}

The effects of different acids on the hydrolysis are shown in table 3. The differences were minor during 60 min incubation. The use of $4 \mathrm{~mol} / 1 \mathrm{HCl}$ and the $60 \mathrm{~min}$ incubation at $+95^{\circ} \mathrm{C}$ was adequate for the hydrolysis

Tab. 3 Effect of different acids on hydrolysis of dopamine and dihydroxyphenylacetic acid conjugates in urine of healthy volunteers during $60 \mathrm{~min}$ incubation at $+95^{\circ} \mathrm{C}$.

\begin{tabular}{lccc}
\hline & $\mathrm{n}$ & $\begin{array}{c}\text { Concentration } \\
(\mathrm{mg} / \mathrm{l})^{\mathrm{a}}\end{array}$ & $\begin{array}{c}\text { Efficacy of } \\
\text { hydrolysis }^{\mathrm{b}}\end{array}$ \\
\hline $\begin{array}{l} \\
\text { Dopamine }\end{array}$ & & & \\
Control & 4 & $0.30 \pm 0.02$ & \\
$4 \mathrm{~mol} / 1 \mathrm{HCl}^{\mathrm{c}}$ & 8 & $1.10 \pm 0.04$ & 265 \\
$4 \mathrm{~mol} / 1 \mathrm{HClO}_{4}{ }^{\mathrm{c}}$ & 6 & $1.12 \pm 0.02$ & 271 \\
$4 \mathrm{~mol} / 1 \mathrm{H}_{2} \mathrm{SO}_{4}{ }^{\mathrm{a}}$ & 6 & $1.14 \pm 0.04$ & 279 \\
& & & \\
Dihydroxyphenylacetic acid & & & \\
Control $_{4 \mathrm{~mol} / 1 \mathrm{HCl}^{\mathrm{c}}}$ & 4 & $0.96 \pm 0.04$ & \\
$4 \mathrm{~mol} / 1 \mathrm{HClO}_{4}{ }^{\mathrm{c}}$ & 8 & $1.93 \pm 0.05$ & 101 \\
$4 \mathrm{~mol} / 1 \mathrm{H}_{2} \mathrm{SO}_{4}{ }^{\mathrm{c}}$ & 6 & $1.87 \pm 0.03$ & 94 \\
& 6 & $1.79 \pm 0.04$ & 86 \\
\hline
\end{tabular}

\footnotetext{
${ }^{\text {a }}$ Mean $\pm \mathrm{SD}$

b $\frac{\text { After hydrolysis }- \text { Before hydrolysis }}{\text { Before hydrolysis }} \times 100$

c Final concentration in hydrolysis mixture $0.52 \mathrm{~mol} / \mathrm{l}$
} 


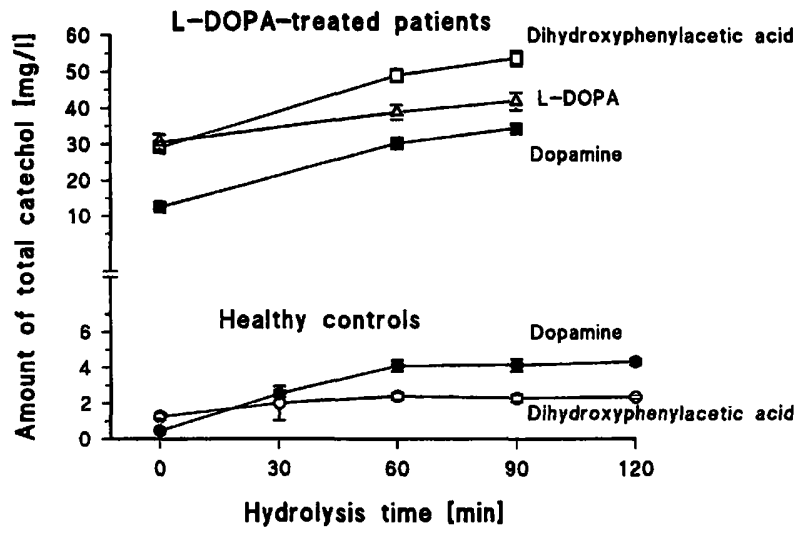

Fig. 3 Effect of hydrolysis time on the liberation of free catechols ( $L$-DOPA, dopamine, dihydroxyphenylacetic acid) as a function of time using $4 \mathrm{~mol} / \mathrm{H} \mathrm{HCl}$ at $+95^{\circ} \mathrm{C}$. Studies were done using urine samples from both healthy controls $(n=4)$ and from patients receiving $L$-DOPA $(\mathrm{n}=4)$. Mean $\pm \mathrm{SD}$.

of conjugated $L$-DOPA, dopamine and dihydroxyphenylacetic acid. The effect of time (30-120 min) on the hydrolysis of urine samples is shown in figure 3 . The hydrolysis was not complete after the $30 \mathrm{~min}$ incubation. There was no difference between $60 \mathrm{~min}$ and $90 \mathrm{~min}$ incubations. $L$-DOPA and dopamine liberation was slightly increased during prolonged incubation but dihydroxyphenylacetic acid levels were rather decreased. However, the compounds did not decompose during acid hydrolysis (fig. 3).

\section{Comparison of healthy volunteers and patients with Parkinson's disease}

An initial comparison was made during the validation process (tab. 2 and fig. 3). Our studies showed that enzymatic hydrolysis was equally effective for urine samples from the healthy controls and from the patients on $L$ DOPA therapy. However, the percentage hydrolysis by acid was much smaller in the latter than in the former urine samples.

In the more precise comparison, the urinary dopamine concentration of 5 control persons varied from 0.23 to $0.47(0.30 \pm 0.10 \mathrm{mg} / \mathrm{l}$; mean $\pm \mathrm{SD})$, and dihydroxyphenylacetic acid concentrations from 1.1 to 5.1 (1.21 $\pm 0.66 \mathrm{mg} / 1$; mean $\pm \mathrm{SD}$ ). In $7 \mathrm{~L}$-DOPA treated patients the concentrations of dopamine were 50-200-fold and those of dihydroxyphenylacetic acid 30-40-fold greater than the control values. Generally, the variations between subjects was several-fold.

In healthy volunteers, with very low free dopamine levels, the quantity of dopamine was increased nearly 9fold by acid hydrolysis, whereas that of dihydroxyphenylacetic acid was increased only 1.5 -fold. Much smaller quantities of catechols were released by enzymatic hydrolysis than by acid hydrolysis, indicating that other conjugates were present in urine, in addition to sulphates. The amounts of these other conjugates showed wide variations, but they usually exceeded those of the sulphate conjugates (tab. 4; fig. 4).

We divided the 7 Parkinsonian patients into two groups based on the free dopamine concentrations before hydrolysis (moderate dopamine, $<20 \mathrm{mg} / \mathrm{l}$, and high dopamine group, $>50 \mathrm{mg} / \mathrm{l}$; tab. 4). In the moderate dopamine group, the proportion of dopamine after acid hydrolysis was increased by $64 \%$ during hydrolysis. Correspondingly, in the high dopamine group the proportion of dopamine was increased only by $30 \%$. After acid hydrolysis the proportion of dihydroxyphenylacetic acid was increased by $48 \%$ in the moderate dopamine group,
Tab. 4 Effect of acid hydrolysis $(4 \mathrm{~mol} / 1 \mathrm{HCl}$ for $60 \mathrm{~min}$ at $\left.+95^{\circ} \mathrm{C}\right)$ and sulphatase treatment $(18.4 \mathrm{U}$ in $400 \mu \mathrm{l}$ reaction mixture for $60 \mathrm{~min}$ at $+37^{\circ} \mathrm{C}$ ) on the liberation of free catechols from the urine of control subjects (low dopamine) and patients treated with $L$-DOPA (moderate and high dopamine concentrations).

\begin{tabular}{|c|c|c|c|c|}
\hline & $\begin{array}{l}\text { Concentration of } \\
\text { catecholamines } \\
\text { released by acid } \\
\text { (= total conjugates) } \\
\text { mg/l } \\
\text { (Mean } \pm \text { SD) }\end{array}$ & $\begin{array}{l}\text { Concentration of } \\
\text { catecholamines } \\
\text { released by sulphatase }\end{array}$ & $\begin{array}{l}\mathrm{mg} / 1 \\
(\mathrm{Mean} \pm \mathrm{SD})\end{array}$ & $\begin{array}{l}\text { Proportion of } \\
\text { other conjugates } \\
\text { from total } \\
\text { conjugates } \\
\%\end{array}$ \\
\hline \multicolumn{5}{|l|}{ Control subjects $(\mathrm{n}=5)$} \\
\hline $\begin{array}{l}\text { Dopamine } \\
\text { Dihydroxyphenylacetic acid }\end{array}$ & $\begin{array}{l}2.6 \pm 3.0 \\
1.6 \pm 1.0\end{array}$ & $\begin{array}{l}0.45 \pm 0.49 \\
0.45 \pm 0.30\end{array}$ & $\begin{array}{l}2.2 \pm 2.5 \\
1.1 \pm 0.7\end{array}$ & $\begin{array}{l}82.0 \pm 7.1 \\
71.0 \pm 6.5\end{array}$ \\
\hline \multicolumn{5}{|c|}{$\begin{array}{l}L-D O P A \text { treated subjects } \\
\text { Moderate dopamine }(<20 \mathrm{mg} / \mathrm{l})(\mathrm{n}=3)\end{array}$} \\
\hline $\begin{array}{l}L \text {-DOPA } \\
\text { Dopamine } \\
\text { Dihydroxyphenylacetic acid }\end{array}$ & $\begin{array}{r}6.3 \pm 2.0 \\
10.7 \pm 5.6 \\
16.7 \pm 18.7\end{array}$ & $\begin{array}{r}1.1 \pm 2.0 \\
4.2 \pm 5.0 \\
10.4 \pm 13.8\end{array}$ & $\begin{array}{l}5.2 \pm 1.1 \\
6.5 \pm 1.3 \\
6.3 \pm 4.9\end{array}$ & $\begin{array}{l}87.7 \pm 22.5 \\
70.9 \pm 27.0 \\
66.3 \pm 37.6\end{array}$ \\
\hline \multicolumn{5}{|c|}{ High dopamine $(>50 \mathrm{mg} / \mathrm{l})(\mathrm{n}=4)$} \\
\hline $\begin{array}{l}L \text {-DOPA } \\
\text { Dopamine } \\
\text { Dihydroxyphenylacetic acid }\end{array}$ & $\begin{array}{r}8.8 \pm 3.0 \\
19.7 \pm 9.7 \\
4.9 \pm 2.2\end{array}$ & $\begin{array}{l}0.0 \\
4.3 \pm 3.8 \\
0.4 \pm 0.6\end{array}$ & $\begin{array}{r}8.8 \pm 3.0 \\
15.4 \pm 6.4 \\
4.6 \pm 1.9\end{array}$ & $\begin{array}{l}100.0 \\
81.6 \pm 16.2 \\
94.5 \pm 8.6\end{array}$ \\
\hline
\end{tabular}




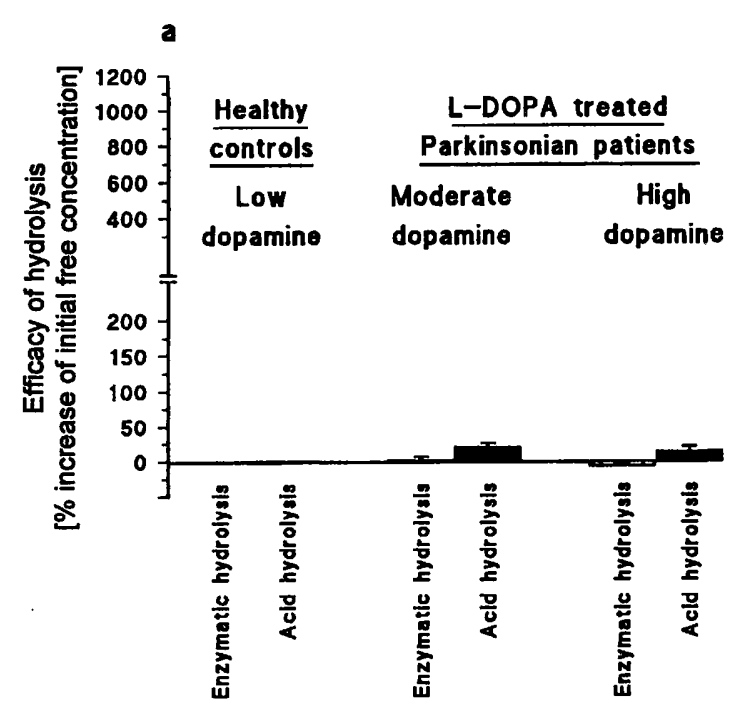

b

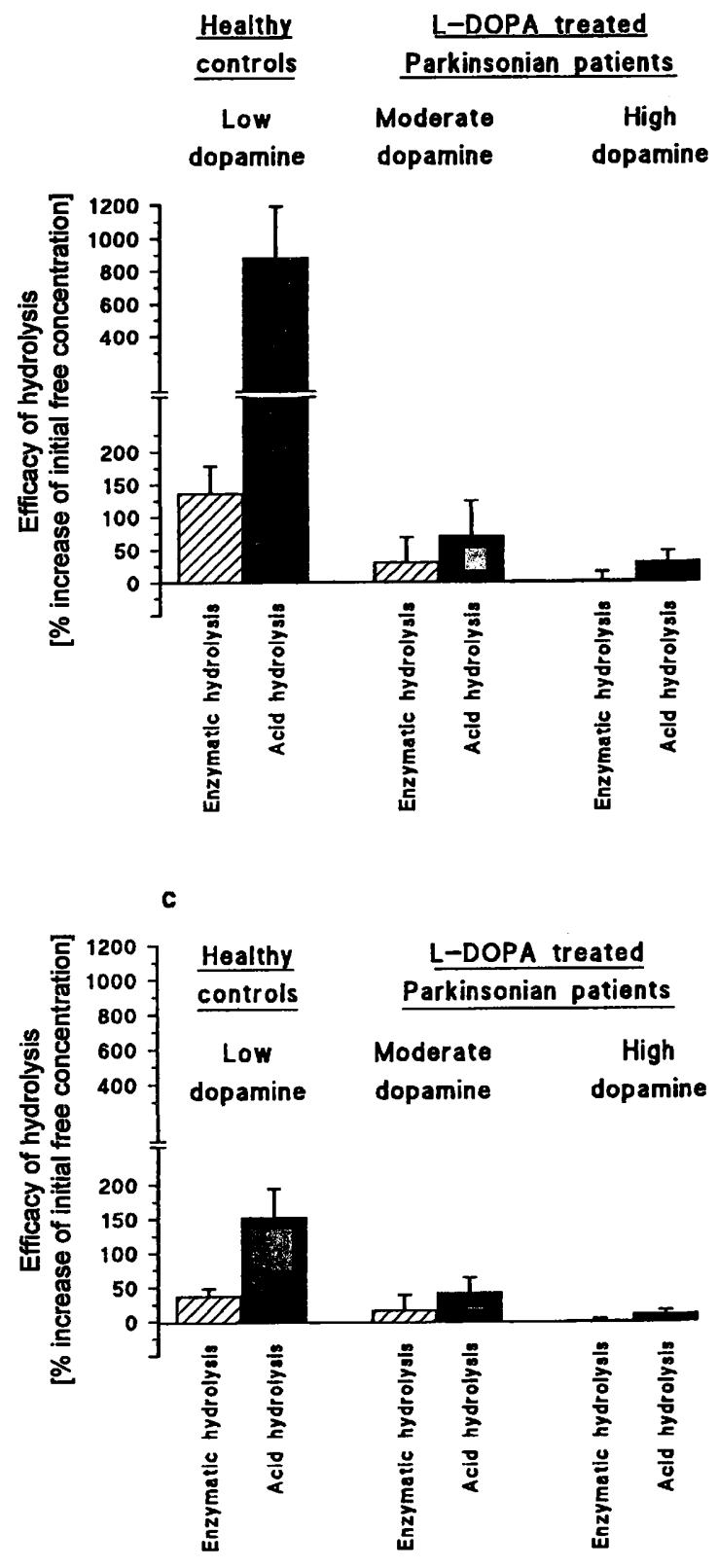

and only by $10 \%$ in the high dopamine group (fig. 4). Only minor quantities of $L$-DOPA conjugates were present, and they were not hydrolysed at all by sulphatase. The overall percentage conjugation of $L$-DOPA, dopamine and dihydroxyphenylacetic acid showed a concentration-dependent decrease, as the concentrations of the free compounds increased (fig. 4).

As in the control group, much smaller quantities of catechols were released by enzymatic hydrolysis, both in the low and the moderate dopamine groups, than by acid hydrolysis, indicating that there were other conjugates in the urine. These other conjugates accounted for 66 to $100 \%$ of the total conjugates (tab. 4; fig. 4).

\section{Discussion}

Since conjugation reactions play a significant role in the metabolism of catecholamines $(1,8)$ it is important to be able to quantify them. We have now compared procedures used to quantify free and conjugated forms of the catechol compounds, $L$-DOPA, dopamine and dihydroxyphenylacetic acid in urine after acid and enzymatic hydrolysis. Basal catechol levels and the quantities of conjugates display marked variations between individuals. Our conclusion is that the use of $4 \mathrm{~mol} / 1 \mathrm{HCl}$ for $60 \mathrm{~min}$ at $+95^{\circ} \mathrm{C}$ gives satisfactory results. The degree of hydrolysis is only slightly increased by $120 \mathrm{~min}$ hydrolysis. Other acids produce similar results after $60 \mathrm{~min}$ incubation for the hydrolysis of the dopamine conjugates, but show different efficiencies of hydrolysis for conjugates of dihydroxyphenylacetic acid. The studies showed that a maximum incubation time of one hour was needed for optimum hydrolysis of the analytes without decomposition. We found that at least $0.52 \mathrm{~mol} / 1$ of $\mathrm{HClO}_{4}$ was needed for adequate hydrolysis in $60 \mathrm{~min}$, which differs from the conditions reported by Elchisak et al. (9). Incubation for a further hour did not increase the hydrolysis.

The enzymatic procedure using sulphatase gives a less complete hydrolysis of conjugated catecholamines. This is partially due to the fact that other conjugates are present, which are not hydrolysed by sulphatase. In fact, non-sulphate conjugates seem to be more abundant than sulphate conjugates. Enzyme preparations are not easy to use; they are sometimes sticky and quite expensive. Therefore acid hydrolysis is generally preferred from a practical point of view too.

Fig. 4 Efficacy of enzymatic (18.4 $\mathrm{U}$ in $400 \mu$ reaction mixture for $60 \mathrm{~min}$ at $+37^{\circ} \mathrm{C}$ ) and acid hydrolysis $(4 \mathrm{~mol} / \mathrm{l} \mathrm{HCl}$ for $60 \mathrm{~min}$ at $+95^{\circ} \mathrm{C}$ ) in healthy volunteers (low dopamine in urine) and in patients receiving $L$-DOPA (divided into moderate and high dopamine groups), where $\mathrm{a}=L$-DOPA, $\mathrm{b}=$ dopamine and $\mathrm{c}=$ dihydroxyphenylacetic acid.

Mean $\pm \mathrm{SD}$. The efficacy is expressed as the percentage increase of the free catechol from the initial free concentration. 
For determination of urinary catecholamines the samples must be collected in acid to avoid spontaneous oxidation (10). However, pH-values less than 1 can decrease the recoveries of catecholamine (11). We collected the urine specimens in $6 \mathrm{~mol} / 1 \mathrm{HCl}$, and $\mathrm{pH}$ remained between 1.5 and 2.0. In many laboratories antioxidants, e. g., ascorbic acid, $\mathrm{Na}_{2} \mathrm{~S}_{2} \mathrm{O}_{5}$ or dithiothreitol $(8,9)$ are added to prevent oxidation during the hydrolysis procedure. We found, however, that the enzyme hydrolysis was inhibited by $1.3 \mathrm{mmol} / 1$ of $\mathrm{Na}_{2} \mathrm{~S}_{2} \mathrm{O}_{5}$ in the incubation solution. It has been reported that the hydrolysis of noradrenaline was considerably inhibited by adding ascorbic acid $(0.5-10 \mathrm{mmol} / \mathrm{l})$ and slightly inhibited by dithiothreitol $(1-10 \mathrm{mmol} / \mathrm{l})$ in plasma (12). On the other hand, the hydrolysis of dopamine was not inhibited by ascorbic acid or dithiothreitol (12). In our hands $\mathrm{Na}_{2} \mathrm{~S}_{2} \mathrm{O}_{5}$ did not affect the acid hydrolysis at all.

Dihydroxybenzylamine is frequently used as an internal standard in catecholamine analyses. Its recovery is the same as that of endogenous catecholamines in human and rodent plasma, while the recovery in dog, horse and goat plasma is rather less than that in human plasma (13). In our hands, the recovery of dihydroxybenzylamine decreased during enzymatic hydrolysis, although the recoveries of catechol compounds did not. Therefore we added dihydroxybenzylamine only after the enzymatic or acid hydrolysis, and before the alumina procedure.

During validation of our method we accidentally found that a large unknown peak appeared during the acid hy-

\section{References}

1. Kopin I. Catecholamine metabolism: basic aspects and clinical significance Pharmacol Rev 1984; 37:333-56.

2. Rosano TG, Swift TA, Hayes LW. Advances in catecholamine and metabolite measurements for diagnosis of pheochromocytoma. Clin Chem 1991; 37:1854-67.

3. Smythe GA, Edwards G, Graham P, Lazarus L. Biochemical diagnosis of pheochromocytoma by simultaneous measurement of epinephrine and norepinephrine. Clin Chem 1992; 38:486-92.

4. Buu NT, Kuchel O. A new method for the hydrolysis of conjugated catecholamines. J Lab Clin Med 1977; 90:680-5.

5. Santagonistino G, Cucchi SPML, Frattini P. Simultaneous measurement of total catecholamines and metanephrines in human urine by liquid chromatography with coulometric detection. Il Farmaco 1991; 46:1217-23.

6. Dutton J, Copeland LG, Playfer JR, Roberts NB. Measuring L-dopa in plasma and urine to monitor therapy of elderly patients with Parkinson's disease treated with L-dopa and a dopa decarboxylase inhibitor. Clin Chem 1993; 39:629-34.

7. Davidson DF, Fitzpatrick J. A simple, optimised and rapid assay for urinary free catecholamines by HPLC with electrochemical detection. Ann Clin Biochem 1985; 22:297-303.

8. Buu NT, Duhaime J, Kuchen O. Effects of L-dopa on the concentrations of free and sulphoconjugated catecholamines in plasma, cerebrospinal fluid, urine and central and peripheral nervous system tissues of the rat. J Neurochem 1985; 44:787-92. drolysis. This seriously marked the detection of dihydroxyphenylacetic acid, since it was extracted in both the alumina and solid phase procedures. Its retention time was insensitive to $\mathrm{pH}$ changes, but when heptane sulphonic acid was used instead of octane sulphonic acid in the mobile phase, we finally succeeded in separating it from the dihydroxyphenylacetic acid peak (fig. 1 and 2). This exemplifies the practical interference problem when working with a biological matrix.

The initial dopamine (and dihydroxyphenylacetic acid) levels seemed to dictate the degree of hydrolysis. These findings are interpreted as follows. At high urinary dopamine (and dihydroxyphenylacetic acid) levels, such as those seen in the $L$-DOPA treated patients, the capacity of conjugation is saturated and the free dopamine (and dihydroxyphenylacetic acid) concentrations are much higher than those in the healthy volunteers. Hydrolysis releases even more dopamine (and dihydroxyphenylacetic acid) from urine of the patients whose conjugation capacity almost or totally exhausted, than from the urine of the healthy controls whose still have a relatively high conjugation capacity. The percentage hydrolysis is decreased in the samples from $L$-DOPA-treated patients, owing to their much higher catechol concentrations.

\section{Acknowledgements}

The excellent technical help of Ms Nada Bechara-Hirvonen and Satu Mäkinen is appreciated. This study was financially supported by the Sigrid Juselius Foundation, Helsinki.

9. Elchisak MA, Carlson JH. Assay of free and conjugated catecholamines by high-performance liquid chromatography with electrochemical detection. J Chromatogr 1982; 233:79-88.

10. Giles HG, Meggiorini S. Stability of catecholamines in urine. Clin Chem 1983; 29:595.

11. Rivero-Marcotequi A, Grijalba-Uche A, Palacios-Sarrasqueta $\mathrm{M}$, Garcia-Merlo S. Effect of the $\mathrm{pH}$ and the importance of the internal standard on the measurement of the urinary catecholamines by high-performance liquid chromatography. Eur J Clin Chem Clin Biochem 1995; 33:873-5.

12. Okada M, Mine K, Fujiwara M. Ascorbic acid suppresses the deconjugation of noradrenaline but not dopamine in plasma. Anal Biochem 1989; 182:262-5.

13. Garty M, Steinmetz Y, Rosenfeld JB, Goldstein DS. Speciesdependent differences in recovery of 3,4-dihydroxybenzylamine in assays of plasma catecholamines. J Chromatogr 1988; 430:123-7.

\section{Received September 13/November 29, 1996}

Corresponding author: Dr. Päivi Tuomainen, University of Helsinki, Institute of Biomedicine, Department of Pharmacology and Toxicology, P. O. Box 8 (Siltavuorenpenger 10), FIN-00014 Helsinki, Finland 
